stringencies in regard to scientific and technical man. power and materials which will be the inescapable consequence of the new defence programme to which Great Britain has now been driven.

\section{FUNDAMENTAL INDUSTRIAL RESEARCH}

Phenomena, Atoms and Molecules: an Attempt to Interpret Phenomena in terms of Mechanisms or Atomic and Molecular Interactions.

By Irving Langmuir. Pp. $\mathrm{x} i+436$. (New York: Philosophical Library, Inc., 1950.) 10 dollars.

A $T$ the end of this book is printed a list of the 215 papers which Dr. Irving Langmuir has written, alone or with his collaborators, since 1906. With fow exceptions, all are first communications of the results of original research and deal with what has come to be known as 'fundamental' science. As the creator of the subject of surface chemistry, Dr. Langmuir was awarded a Nobel Prize in 1932, and men of science the world over have honoured him. This book, which collects together twenty of his chief papers in their original form and gives a complete bibliography, is a testimony of his eminence.

The bibliography groups the two hundred-odd papers into the following eight sections: general topics, scientific research, philosophy of science, incentives in science and in industry, and scientific education; structure of matter, of molecules, atoms, crystals, proteins, and ferromagnetic materials; conduction, convection and radiation of heat, diffusion, evaporation in vacuum and in gases, and gas-filled incandescent lamps, etc.; mechanism of chemical reactions at high temperatures and low pressures, and catalysis; high-vacuum phenomena, vacuum pumps, electron emission and space-charge effects ; electric discharges in gases, especially at low pressures; surface chemistry, adsorption, surface tension, monomolecular films, and biological applications; meteorology and related fields, aviation, oceanography, turbulent motion of water and air, submarine detection by use of the binaural effect, precipitation static and icing of aireraft.

This record, admirable though it be, is not the uniquely remarkable feature of Dr. Langmuir's career. What is surprising is that all this fundamental work was done in an industrial research laboratory. It could not have been done in a British industrial laboratory during these past forty years, and I doubt very much whether it could be now. It would be misleading to argue from this one exceptional case that American industrial research is more imaginative than British and allows greater freedom to its workers. In both countries the industrial laboratory is all too often merely called upon after trouble has occurred and is not encouraged to think up anything new. There are, of course, magnificent exceptions, but the great majority of industrial scientists are concerned with matters only after lack of knowledge of them has caused difficulties. The real truth of the matter is that it is regrettably rare in either country--or elsewhere, for that matter-for a large concern, once having picked a good man, simply to leave him to follow his bent.

"During these first few years", says Dr. Langmuir, "while I was thus having such a good time satisfying my curiosity and publishing scientific papers on chemical reactions at low pressures, I frequently wondered whether it was fair that I should spend my whole time in an industrial organization on such purely scientific work, for I confess I didn't see what applications could be made of it, nor did I even have any applications in mind. Several times I talked the matter over with Dr. Whitney, saying that I could not tell where this work was going to lead us. $\mathrm{He}$ replied that it was not necessary, as far as he was concerned, that it should lead anywhere". This was during 1909-12. Not the least interesting parts of the book are those in which Dr. Langmuir describes how he came to do a classical piece of research and what applications eventually sprang from it. The General Electric Co. of America has presumably had no reason to regret its broad-minded and open-handed attitude.

There is still, and not only in Great Britain, an insufficient appreciation of the importance of the genuine discoverer within industry. It is generally felt in Britain that fundamental research can be left to the universities-indeed, many firms back their faith in them with substantial and conditionless money payments. It is not so much nowadays that industrialists do not believe in fundamental science but that they elevate it beyond their reach. While university 'dons' are treated with exaggerated respect as high priests to be propitiated and occasionally consulted, their own scientific employees are kept in their proper subordinate place. I think the fact of the matter is that the traditional British business man is rather frightened of science; he knows now (rather belatedly) that he has to have it, but the way he intends to get it is very often like this. It would never do to have a man pursuing truth for truth's sake on the firm's own premises-it would unsettle everyone and make things difficult to run. Genius is always an awkward bedfellow.

If one adopts a conservative attitude, this is a perfectly reasonable point of view. The man of science is paid to improve the products, to increase production and lower costs-nothing more. If anything a little more fancy is needed, one can always consult a university professor.

But this is not the way that whole new industries are built, nor, fortunately, is it the universal custom. The more progressive and less traditional the industry, the more intelligent the way in which scientific workers are used within it. One cannot help feeling, however, that we have still to discover the technique of carrying on pure research side by side with the development and application (if any) of its fundamental discoveries. Science is universal, and it is stupid to separate one aspect from another.

In that spring of the post-war world, when men optimistically planned the future, it was indeed often enough said that scientific research was vital to the nation's progress. Later, the dismal pressure of events led, as usual, to a more hard-headed appraisal. What is needed, we are now told, is the translation into industrial practice of already known results. While there can be no doubt that our immediate problems of production should be viewed in this light, it would be a disaster if, thereby, there occurred a reaction against research proper in the industrial field. The future greatness of Great Britain will not lie in a mere routine application of established scientific fact. This is the lesson to be learnt from Dr. Langmuir's book.
D. P. Riley 